\title{
EUROPEAN UNION COMMON SECURITY AND DEFENCE POLICY AND LATVIAN INVOLVEMENT IN EU BATTLEGROUPS
}

\author{
Valerijs BODNIEKS ${ }^{*}$ \\ ${ }^{1}$ Riga Stradinš University, Latvia
}

\begin{abstract}
In this article, the author analyses types of Europeanisation: top-down, bottom-up, horizontal, circular, and looks at Latvian involvement in the EU CSDP capability project - EU Battlegroups. Additionally, the author analyses the EU CSDP strategies in 2003 and 2016 with emphasis on key threats and key directions of action for the security of the EU. If it is necessary, EU Battlegroups can become involved to secure the EU. In the article, the author examines Latvian involvement in EU Battlegroups and changes in political planning documents and legal acts regarding EU Battlegroups. The author shows that for the future, it is necessary to involve an EU Battlegroup in real action in the area of operations, and that it is necessary to initiate discussions on a possible review and evaluation of the format of the EU Battlegroup.
\end{abstract}

Keywords: EU Common Security and Defence policy, defence, security, EU Battlegroups.

\section{Introduction}

The international order of power and strength among states and other international actors is relatively divided in to different proportions. The existing international order is influenced by countries with the main purpose of shaking and changing it.

* Corresponding author: valerijs.bodnieks@inbox.lv

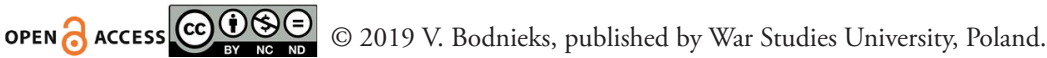

This work is licensed under the Creative Commons Attribution-NonCommercial-NoDerivatives 4.0 License. 
The attempt to change or a failure to act in accordance with the existing international order can be explained as a transition period to a different order. The attempts to reject world order transformation can be interpreted as a transformation and transiti-on to a different, unprecedented new order, or the changes in the existing world order with deeper understanding of the past. Changes in the existing world order can be a risk or challenge, or a chance for new countries to gain their sovereignty and integrity. From the historical point of view, the effects of the First World War, the Second World War and the Cold War are the most visible examples of changes in the world order, which manifests itself in the interaction of European countries. Such events are breaking points in the existing world order. Similarly, as has already happened, the modern world is in a period of transition and global changes, with an emphasis on security and defense issues that are based on insecurity near the borders of Europe.

There are three main challenges for Europe and world security today - Russia's aggression, international terrorism and the activities of terrorist groups, and mass migration. For Latvia and other EU countries, the most important challenge is to maintain the EU and each country's sovereignty and territorial integrity. Since Latvia joined NATO and the EU in 2004, Latvia's defence policy is based on membership in these organisations. The strategic direction is participation in NATO, but the EU is a secondary actor in Latvian defence. Latvian history, geography, culture and participation in NATO and the EU provide a link to every part of the world. Despite the fact that the EU has a secondary actor's role in Latvia's defence, Latvia is involved and participates in the EU Common Security and Defence policy (thereinafter - CSDP).

The article is based on the theoretical framework of Europeanisation, historical aspects of the CSDP, focusing on the development of the EU's military capability and EU Battlegroups. The article analyses the European Security Strategy in 2003 and EU Global Strategy in 2016, Latvian defence strategic documents etc. Focus in the article is put on EU Battlegroups and Latvian involvement in the EU Battlegroups and the future of EU Battlegroups.

\section{Theoretical aspects}

It is difficult to define what Europeanisation is because there are a lot of different definitions to the term. T. Flochart stated that the Europeanisation field is rich in definitions of Europeanisation, and a single and precise meaning of the term remains 
elusive; definitions are specific to individual pieces of work with no clear overall agreement on which direction of the Europeanisation concept should be taken, nor on how far back the concept should reach. (Flochart 2010, p. 789). N.T.T. Hang concludes that some consider Europeanisation as a top-down process in which attention is paid to the impact of the EU on the political institutions, policies and political forces of the member states, but others argue that it is necessary to view it from bottom-up and with a horizontal approach. (Hang 2011, p. 136). At the same time, N.T.T. Hang explains that the term Europeanisation in its broadest meaning can be understood as becoming more European like (Hang 2011, p. 137).

There are four approaches of Europeanisation: bottom-up, top-down, horizontal and circular (a two way) approach. T.A. Börzel and D. Panke explain bottom-up Europeanisation as analyses in the frame of how states upload their domestic preferences to the EU level (Börzel and Panke 2013, p. 120). T.A. Börzel and D. Panke explain that in the top-down Europeanisation, focus is on how the EU shapes institutions, processes, and political outcomes in both: member states and third countries; the topdown approach searches for causes at the EU level that explain domestic changes. (Börzel and Panke 2016, p. 111). The Circular (a two-way) approach is the most complicated. R.J. Vale, by referring to L. Quaglia et all, explains that circular Europeanisation explains Europeanisation as the result of a bidirectional process where member states shape EU policies and institutions by uploading their own policies and institutions to the European level and then adapt to outcomes made at the EU level by 'downloading' EU policies and institutions into the domestic arena (Vale 2011). C. Major and K. Pomorska define horizontal Europeanisation as the exchange of ideas, norms and ways of doing things between countries or other entities for which the EU sets the scene; thus change is not only due to but takes place within Europe (Major and Pomorska 2005, p.13). Top-down Europeanisation means incorporation of the EU defence politics into national level. The main focus in the article is on EU Battlegroups and Latvian involvement in EU Battlegroups. 


\section{EU Defence strategy and EU capability project - The EU Battlegroups}

The EU is an economic power and at the same time, the EU is progressively developing common security and defence policies. From the historical aspect, the EU CSDP formation process was difficult and comprises lots of different events and signed documents. Today, the EU CSDP is an integral part of EU Common Foreign and security policy (thereinafter - CFSP); the CSDP legal and political basis can be found in the Lisbon treaty. The EU is now not just an economic power, but it is also gradually becoming a defence power. According to A.Kotty, based on I.Manner, the EU is a distinctive and perhaps sui generis power: more than a traditional international organisation, yet not a centralised national state, a power. This is because of its internal make-up and, in contrast to past great powers, it emphasises norms, co-operation and soft power in its external behaviour (Cottey 2007). At the same time, C.Arher concludes that the EU may not be seen as a traditional military alliance such as NATO, but it has elements that reflect G.Snyder's definition - they are formal associations of states for the use (or non-use) of military force, in specified circumstances, against states outside their own membership (Archer 2010).

The EU has its own path with incredible development not only in the economic field, but also in security and defence since the creation of the Western European Union. The CSDP's most important documents and events are displayed and summarised in Table 1.

Table 1. CSDP most important documents and events

\begin{tabular}{|l|l|}
\hline Year & Document/Event \\
\hline $1948-1954$ & $\begin{array}{l}\text { Treaty of Brussels, Amendment of the Treaty of Brussels, Creation of the } \\
\text { Western European Union }\end{array}$ \\
\hline 1951 & Treaty of Paris, Creation of European Coal and Steel Community \\
\hline 1969 & Davignon report on Political cooperation \\
\hline 1970 & European Political Cooperation is set up \\
\hline 1992 (in force 1993) & Maastricht Treaty (Creation of the EU) \\
\hline 1997 (in force 1999) & Treaty of Amsterdam \\
\hline 1998 & Senmalo Declaration \\
\hline 1999 & Colonel and Helsinki European Council declaration \\
\hline 2000 & Santa Maria De Feira European Council declaration \\
\hline 2002 & Berlin plus agreement \\
\hline 2003 & $\begin{array}{l}\text { First CSDP mission and operation } \\
\text { European Security strategy } \\
\text { Adopting of the Berlin Plus Arrangements }\end{array}$ \\
\hline
\end{tabular}




\begin{tabular}{|l|l|}
\hline Year & Document/Event \\
\hline 2004 & $\begin{array}{l}\text { Headline goal 2010, decision to create EU Battlegroups } \\
\text { Council of the European Union set up Athena } \\
\text { Establishment of European defence agency }\end{array}$ \\
\hline 2007 (in force 2009) & $\begin{array}{l}\text { The Lisbon treaty (New framework of institutions, decision making and } \\
\text { activities in the CSDP). }\end{array}$ \\
\hline 2008 & $\begin{array}{l}\text { EU High Representative Javier Solana Report on the implementation of } \\
\text { the European Security Strategy - Providing Security in a Changing World }\end{array}$ \\
\hline 2016 & $\begin{array}{l}\text { EU Global Strategy } \\
\text { Council conclusions on implementing The Global EU strategy in the area } \\
\text { of Security and Defence } \\
\text { Implementation Plan on Security and Defence } \\
\text { European Parliament resolution on the European Defence union }\end{array}$ \\
\hline 2017 & PESCO \\
\hline
\end{tabular}

EU Battlegroups is one of the EU capability projects and one of the elements of the EU CSDP development process. In April 2004, the EU Military Committee adopted the establishment of EU Battlegroups. Basically, EU capability projects are necessary to deal with key threats and key directions of action for security of the EU. These directions are mentioned in the European Security Strategy - A Secure Europe in a Better World 2003 (thereinafter - EU Strategy 2003) and in A Global Strategy for the European Union's Foreign and Security Policy - Shared Vision, Common Action: A Stronger Europe 2016 (thereinafter - EU Strategy 2016 (EEAS 2016)). If we compare both documents, it can be seen that the situation of the creation of both documents is similar, because in 2003, the United States, along with coalition forces primarily from the United Kingdom, initiated the war on Iraq, and Russia initiated aggression in Ukraine in 2014. Both events were some sort of fracture points in the existing world order, and they created insecurity near EU borders.

It was incorporated into Strategy 2003 that aggression against any Member State is improbable and Europe has different key threats:

- terrorism - is well sponsored and well resourced, terrorists are connected by electronic networks and are willing to use unlimited violence causing massive casualties, and logistical bases for Al Qaeda have been found in different countries of the EU (UK, Italy, Germany, Spain and Belgium);

- proliferation of Weapons of Mass Destruction - challenge with arms race for WMDs in the Middle East, the proliferation of biological weapons, chemical and radiological weapons and the potential risk that weapons of this kind could also fall into the hands of terrorists; 
- regional conflicts - the conflict in the Middle East or other frozen conflicts near European borders, because conflicts destroy infrastructure and human lives, threaten stability and peace in all regions;

- State Failure - arising from bad governance, corruption, abuse of power, weak institutions; such state collapse can be an obvious threat;

- Organised Crime - the EU is a prime target, external dimension: cross-border trafficking (EU Global Strategy 2003).

- Strategy 2003 defines that to fight against and prevent these threats, the EU should be more:

- active - the need to be able to act before countries around the EU deteriorate, when signs of proliferation are detected, and before humanitarian emergencies arise, preventive engagement can avoid more serious problems in the future - including early, rapid, and when necessary, robust intervention);

- more coherent and more capable - transfer EU militaries into more flexible, mobile forces, and to enable them to address the new threats, more resources for defence and more effective use of resources, systematic use of pooled and shared assets to reduce duplication, increase capabilities - wider spectrum of missions;

- working with partners - common action and coordination of Member States' actions, bringing together all capabilities, important sharing of common threats with all closest partners, international cooperation with key actors and in international organisations (EU Global Strategy 2003).

The main goal for the EU is to achieve readiness and ability to deter, respond, and protect Europe against external threats. According to the new EU Strategy 2016, the key threats/key directions of action for the security of EU are:

- Security and defence - their importance lies in the fact that Europeans must be better equipped, trained and organised not just to engage together with NATO, but also to act autonomously, if and when necessary;

- Counter - terrorism - this entails shared alerts on violent extremism, terrorist networks and foreign terrorist fighters, as well as monitoring and removing unlawful content from the media;

- Cyber Security - support political, operational and technical cyber cooperation between Member States, notably on analysis and consequence management, and foster shared assessments between EU structures and the relevant institutions in Member States; 
- Energy Security - includes internal and external dimensions of European energy security, the EU will move to achieve Energy Union, will seek to diversify its energy sources, routes and suppliers, particularly in the gas domain, as well as to promote the highest nuclear safety standards in third countries;

- Strategic Communication - The EU will enhance its strategic communications, investing in and joining up public diplomacy across different fields, the EU will improve the consistency and speed of messaging on EU principles and actions (EU Global Strategy 2016). For a better comparison, a composition of different threats and key directions of action for the security of the EU can be seen in Table 2:

Table 2. Key threats / key directions of action for the security of the EU

\begin{tabular}{|l|l|}
\hline EU Strategy 2003 & EU Strategy 2016 \\
\hline Terrorism & Security and Defence \\
\hline Proliferation of Weapons of Mass Destruction & Counter-terrorism \\
\hline Regional Conflicts & Cyber Security \\
\hline State Failure & Energy Security \\
\hline Organised Crime & Strategic Communication \\
\hline
\end{tabular}

In order to combat various types of internal or external challenges, the only issue which remains is the actual capabilities of the EU at the tactical and operational level. The total capacity of the EU is the individual capabilities of each Member State, which must be combined with various mechanisms of the EU's capabilities. As an example, one of the following directions manifests itself in the EU's mission, and the other in the EU Battlegroups.

The EU Military Committee approved the concept of EU Battlegroups in 2004. The EU Battle Group achieved full combat readiness at the beginning of 2007. The main idea is to establish multinational combat units with support elements capable of initiating a military operation within ten days and maintaining themselves for at least 30 days without additional supplies, and up to 120 days with additional supplies; the EU Battle group should be deployed in the operational region for five to ten days (Mil.lv 2019). EU Battlegroups are multinational, military units, usually composed of 1500 personnel each and form an integral part of the European Union's military rapid reaction capacity to respond to emerging crises and conflicts around the world (EEAS - European External Action Service 2018). From the military aspect, a battalion typically consists of 300 to 800 soldiers and a battalion is a minimum unit which can freely operate in the area of operations. Their deployment is subject to a unanimous decision by the Council; 
a decision of the Council would generally require an authorising UN Security Council Resolution (EEAS - European External Action Service 2018).

According to information from the EU External action service, EU Battlegroups is a tool for defence cooperation, but there are several reasons why they haven't been fully used: issues relating to political will, usability, and financial solidarity (EEAS - European External Action Service 2018). Today, when there are so many challenges near the EU's borders, and the main question is still about the potential aggression of Russia, European cooperation on defence is vital, and one way to do is use EU Battlegroups.

Latvia has participated in EU Battlegroups several times since 2004, when it took part in the first Military Capabilities Commitment Conference. Basically, before participating in an EU Battlegroup, countries sign a letter of intent, followed by a Memorandum of Understanding (thereinafter - MoU). It is not essential to list all letters of intent and $\mathrm{MoU}$ about Latvia's participation in EU Battlegroups, but it is important that $\mathrm{MoU}$ countries determine the basic principles of the concrete EU Battlegroup, management/ command and control, security issues, structure, training and other issues, thus ensuring the readiness of the EU Battlegroup to engage in operations (Mod.gov.lv 2019a). In 2010, EU Battlegroup Latvia was included in the multinational Military Police unit; the unit was led by the Military Police of the Polish Armed Forces. In addition, in the first half of 2010, an unexploded ammunition neutralisation unit and the National support group and staff from headquarters also participated in the EU Battlegroup. (Mil.lv 2019).

In 2013, the Latvian National Guard and personnel from Headquarters participated in the EU Battlegroup, which was the first time that the National Guard took part in the EU Battlegroup. During the first half of 2015, Latvian soldiers carried out combat duty in the Swedish-led EU Battlegroup, serving in the rapid reaction unit. In the second half of 2016, Latvia participated in the EU Battlegroup, led by the British (Mil.lv 2019). The main task of Latvia's contingent was to provide assistance to EU Member States and other requesting countries, in which a crisis had arisen that could not be resolved diplomatically, or when external or internal military threats, a violent disturbance of the peace by a crowd or conflict materialised (Mil.lv 2019). A summary of Latvia's membership in the EU Battlegroups is shown in Table 3. Latvia's support for EU Battlegroups can be seen in policy planning documents (State Defence Concepts) (Mod.gov.lv 2019b) and legal acts, for example - the law on Participation of the Latvian National Armed Forces in International Operations (Likumi.lv, 1995). 
Table 3. Summary of Latvia's membership in EU Battlegroups (Mil.lv 2019)

\begin{tabular}{|l|l|l|l|l|}
\hline Unit & Duration & Leading nation & Participants & Latvia's membership \\
\hline $\begin{array}{l}\text { EUBG } \\
2010 / 1\end{array}$ & 2010 & Poland & $\begin{array}{l}\text { Latvia, Lithuania, Slovakia, } \\
\text { Germany }\end{array}$ & 69 soldiers \\
\hline $\begin{array}{l}\text { EUBG } \\
2013 / 2\end{array}$ & 2013 & UK & $\begin{array}{l}\text { Latvia, Lithuania, } \\
\text { Netherlands, Sweden }\end{array}$ & $\begin{array}{l}96 \text { national guard and } \\
\text { soldiers }\end{array}$ \\
\hline $\begin{array}{l}\text { EUBG } \\
2015\end{array}$ & 2015 & Sweden & $\begin{array}{l}\text { Latvia, Lithuania, Estonia, } \\
\text { Norway, Finland, Ireland }\end{array}$ & 160 soldiers \\
\hline $\begin{array}{l}\text { EUBG } \\
2016\end{array}$ & 2015 & UK & $\begin{array}{l}\text { Latvia, Finland, Ireland, } \\
\text { Lithuania, Sweden }\end{array}$ & $\begin{array}{l}103 \text { national guard and } \\
\text { soldiers }\end{array}$ \\
\hline
\end{tabular}

Battlegroups are employable across the full range of tasks listed in Article 43(1) of the Treaty on European Union and those identified in the context of the implementation of the EU Global Strategy, these include: conflict prevention, initial stabilisation, humanitarian interventions and rescue tasks, crisis management, and peacekeeping. Therefore, EU Battlegroups should be used with all their capacity, not only as an exercise opportunity for armed forces, but also as a real asset in the hands of all EU countries. For Latvia, participation in EU Battlegroups is an opportunity for solidarity, strengthening of collective cooperation with partner countries, and experience gained by military personnel, which is passed on during training, and financial benefits from joint purchase. The future projects of EU countries' cooperation are listed under CSDP Permanent Structural Cooperation (PESCO), but all EU member states are, nevertheless, not allowed to forget about cooperation in the EU Battlegroup format, because it is an EU capability project, which should be used on the tactical and operational level to solve different threats. At the same time, the EU can forge its own path to become a more credible security and defence actor that supplements NATO. If it is necessary, the EU should and can react using its own force and capabilities.

\section{Conclusions}

The main focus in Latvia's defence policy is on participation in NATO, but it is given a secondary defence actors role in the EU. This is self-evident in the capacity of organisations. The EU, by creating and developing EU CSDP, has become a more credible defence and security actor in the international arena. There are various types of threats and key directions for the security of the EU (terrorism, regional conflicts, cyber 
security, defence etc.). One of the EU's capacity-building projects in the framework of the CSDP is the EU Battlegroups, which is a good format for national co-operation and capacity building. From the theoretical perspective of Europeanisation, the EU CSDP and the requirement to participate in EU Battlegroups is integrated into Latvia's political planning documents and legal acts. At the same time, Latvia also actively involves professional soldiers and the National Guard in EU Battlegroup activities on the tactical and operational level. In the future perspective, EU countries will focus on participation in PESCO projects, but, at the same time, it is necessary to pay more attention to EU operability on the tactical and operational level, because it is a real force which may be needed. Such force is and can be in the future - the EU Battlegroups; therefore, it is necessary to involve the EU Battlegroup in real action in the area of operations, as well as initiating discussions on a possible review and evaluation of the format of the EU Battlegroup.

\section{References}

Archer, C., 2010. Small States and the Europen Security and defence Policy. In: R. Steinmets and A. Wivel, ed. Small States in Europe Challenges and Opportunities. London: Ashgate Publishing Limited.

Börzel, T.A. and Panke, D., 2013. Europeanization. In: M. Cini and N.P.S.Borragan, ed. European Union Politics. 4th ed. Oxford: Oxford University Press. 115-128.

Cottey, A., 2007. Security in the new Europe. Basingstoke England: Palgrave Macmillan.

Flochart, T., 2010. Europeanization or EU-ization? The Transfer of European Norms across Time and Space. JCMS: Journal of Common Market Studies, 48(4), pp.787-810. [online]. Available from: https://www.academia.edu/2018449/Europeanization_or_EU_ization_ The_Transfer_of_European_Norms_across_Time_and_Space?auto=download [Accessed 15 Oct 2018].

Hang, N.T.T., 2011. Europeanization: Simply a Top-down Process? Marmara Journal of European Studies, 19 (1), 135-151. Available from: http://dosya.marmara.edu.tr/avrupa/mjes\%20 arsiv/vol\%2019\%201\%20/6-hang.pdf [Accessed 15 Oct 2018].

Major, C. and Pomorska, K., 2005. Theorising the Effects of the CFSP on National Foreign Policy and the Concept of Europeanisation. A network of research and teaching on European Foreign Policy: CFSP Forum, 3(5). [online]. Available from: http://www.lse.ac.uk/ internationalRelations/centresandunits/EFPU/EFPUpdfs/CFSPForum3-5.pdf [Accessed 15 Oct 2018].

Vale, J. R., 2011. Is 'Europeanization' a Useful Concept?. [online]. E-International Relations. Available from: http://www.e-ir.info/2011/01/17/is-\%E2\%80\%98europeanization\%E2\% 80\%99-a-useful-concept/ [Accessed 15 Oct 2018]. 
EU Global Strategy., 2003. European Security Strategy - A Secure Europe in a Better World EU Global Strategy - European Commission. [online]. Available from: https://europa.eu/ globalstrategy/en/european-security-strategy-secure-europe-better-world [Accessed 14 Oct 2018].

Likumi.lv., 2018. Participation of the Latvian National Armed Forces in International Operations. [online]. Available from: https://ikumi.lv/ta/en/en/id/34028-participation-of-the-latviannational-armed-forces-in-international-operations [Accessed 14 Oct 2018].

EEAS - European External Action Service, 2016. Shared Vision, Common Action: A Stronger Europe. [online] Available from: https://eeas.europa.eu/archives/docs/top_stories/pdf/eugs_ review_web.pdf [Accessed 14 Oct 2018].

EEAS - European External Action Service., 2018. EU Battlegroups - EEAS - European External Action Service - European Commission. [online]. Available from: https://eeas.europa.eu/ headquarters/headquarters-Homepage/33557/eu-battlegroups_en [Accessed 14 Oct. 2018]. Mod.gov.lv., 2019a. Ministry of Defence of the Republic of Latvia. [online]. Available from: https:// www.mod.gov.lv/en/node/482 [Accessed 7 Apr 2019].

Mod.gov.lv., 2019b. Ministry of Defence of the Republic of Latvia. [online]. Available from: https:// www.mod.gov.lv/lv/dokumenti [Accessed 7 Apr 2019].

Mil.lv., 2019. National Armed forces. [online]. Available from: https://www.mil.lv/en/node/616 [Accessed 7 Apr 2019].

\section{Author:}

Valerijs Bodnieks MSc

Riga Stradiņš University, Latvia 